\title{
In-Between an Economic Freedom and a Human Right: A Hybrid Right to Private Property
}

\author{
Lisa Mardikian ${ }^{\star}$
}

Lecturer in Property Law, Brunel University London, London, United Kingdom lisa.mardikian@brunel.ac.uk

$\begin{array}{lr}\text { Abstract } & 341\end{array}$

$\begin{array}{ll}\text { Keywords } & 342\end{array}$

I. Introduction $\quad 342$

II. Reinterpreting the Right to Property as a Hybrid 346

1. Hybridity and the Right to Property 349

III. Judicial Interpretation of the Right to Property under Transnational Conditions 354

1. Property in the ICJ: A Transnational Economic Freedom from a State-centred Perspective

2. Beyond Dichotomies: A Hybrid Right to Property in the European Space of Governance

a) A Right to Property as an Aspect of the Human Rights and Economic Integration Agendas

b) The Economic and Social Dimensions of Property 369

IV. Hybridity Beyond Private Property: Indigenous Rights and the IACtHR 376

$\begin{array}{lr}\text { V. Conclusion } & 379\end{array}$

\begin{abstract}
The objective of this article is to examine the right to private property in the international and European legal orders and to explore the relevant case law of the International Court of Justice, the Court of the European Union, and the European Court of Human Rights. In so doing, the analysis will focus on whether the right is identified as an economic freedom or a human right by the different courts in the context of these legal orders. It will unpack the conceptual challenges that the variegated standards of protection present in formulating an understanding of the right to property from the perspective of a systems theoretical approach. In light of this, the article will seek to determine how property can be framed under conditions of func-

\footnotetext{
* I would like to thank Achilles Skordas for his valuable comments on an earlier version of
} this article, as well as the anonymous reviewers for their constructive remarks.
\end{abstract}


tional differentiation in a multiplicity of operations in the economy, politics, and law, and to highlight its polyvalent nature. It is argued that the nature of the right to property is not binary and antithetical; not solely an economic freedom neither exclusively a human right. Instead, the two forms are intrinsically interrelated, thereby leading to the emergence of its hybridisation. It is further shown that this characteristic of hybridity manifested in the reasoning of the courts is translated into a legal - justiciable - formulation that can integrate the different sides of property as partially complementary. The relationship between the two dimensions, therefore, allows for a possibility of evolution and adjustment of the right's content and application.

\section{Keywords}

Property - hybridity - human rights - economic freedoms - systems
theory

\section{Introduction}

The objective of this article is to examine the right to property in the international and European legal orders and to discuss the relevant case law of the International Court of Justice (ICJ), the Court of the European Union (CJEU), and the European Court of Human Rights (ECtHR). In so doing, the analysis focuses on whether the right is identified as an economic freedom or a human right by these courts in the context of the legal orders in which they operate. It unpacks the conceptual challenges that the variegated standards of protection present in formulating an understanding of the right to property from the perspective of a systems theoretical approach. In light of this, the article seeks to determine how property can be framed under conditions of functional differentiation in a multiplicity of operations in the economy, politics, and law, and to highlight its polyvalent nature. Two main arguments are put forward in this direction.

The first is that the nature of the right to property is not binary; not solely an economic freedom neither exclusively a human right. Instead, the two forms are intrinsically interrelated, thereby leading to the emergence of its hybridisation. Viewed as an economic freedom, property is meant to regulate private relations of economic actors on the market and their participation in profitable economic exchange. From this perspective, property constitutes a fundamental institution of the economic system alongside contract. As a 
human right, it entails limits to the exercise of arbitrary political power and is therefore a key element of a democratic society that ensures the inclusion of the individual in various social spheres and activities in modern society.

The tensions between the economic and non-economic sides of property are, by no means, a new phenomenon. The possibility of identifying a degree of compatibility between the two, however, has not been as readily accepted in the legal literature. Property has been broadly perceived with scepticism because it has been tied to specific historical and social experiences: it has been associated with the promotion of economic interests of colonial powers, ${ }^{1}$ the entrenchment of socioeconomic inequality, ${ }^{2}$ and the furtherance of racial and gender inequities, ${ }^{3}$ whereas the desirability of recognising a general and substantive right to property has been strongly contested. ${ }^{4}$ This renders the enquiry on the hybridisation of the right pertinent. In this light, the analysis in this article departs from an antithetical and mutually exclusive understanding of the economic and non-economic sides of property. It is built on the hypothesis that the relationship between the two allows for a possibility of evolution and adjustment of the right's content and application.

The second argument is that the interactions between the different dimensions of property can be managed by international courts. The varying degrees to which this has been achieved can be demonstrated by the case law of the ICJ, the ECtHR, and the CJEU. While there are obvious differences in the way that these courts conceptualise the right, it becomes apparent that its transnational protection indicates the dynamic and polycontextual nature of the right. The ICJ has identified property within the ambit of universal customary law on the international minimum standard and has construed it as a transnational economic freedom. ${ }^{5}$ In its regional formulation in Europe, property is differentiated between the EU, the Council of Europe and the member states to both organisations. The jurisprudence of the CJEU and the ECtHR may appear 'messy' and inconsistent, but the two courts have built a 'reflexive web of "similar" judgments"6

1 Martti Koskenniemi, 'Sovereignty, Property and Empire: Early Modern English Contexts', Theoretical Inquiries in Law 18 (2017), 355-389.

2 Harvey M. Jacobs, 'Private Property and Human Rights: A Mismatch in the 21st Century?', International Journal of Social Welfare 22 (2013), S85-S101.

3 Cheryl I. Harris, 'Whiteness as Property', HLR 106 (1993), 1707-1791; Bina Agarwal, A Field of One's Own: Gender and Land Rights in South Asia (Cambridge: Cambridge University Press 1994), 12-17.

4 Tim Hayward, Human Rights vs Property Rights, Just World Institute Working Paper No. 2013/04.

5 See Section III. on this point.

6 Karl-Heinz Ladeur, The Evolution of General Administrative Law and the Emergence of Postmodern Administrative Law, Osgoode CLPE Research Paper 16/2011, 46. 
that integrates, and can switch between, the different sides of the right. Transnationality, in this sense, can be viewed as a separate manifestation of the hybridity of property operating in-between social practices that have specific logics of their own and that emerge not only within states, but in the transnational sphere too. ${ }^{7}$

A hybrid understanding of property leads us to a key conclusion regarding the jurisprudence of the courts analysed here. In relation to property, judgemade law has expanded drastically in the transnational context and enables us to understand property beyond the classical dichotomies of private/public law and international/domestic law. The courts do not operate within their own legal silos but develop jurisprudence that contributes to a global discourse about property and economic governance. ${ }^{8}$ They are part of this discourse that shapes the interpretation of property and they have been able to respond to disputes that underline the hybridity of the right.

The aim in this article, however, is to provide a broader examination of the social dynamics that drive forward the conceptualisation of property, so that it does not remain limited to mutually exclusive categorisations. The hybridity of property manifested in the reasoning of the courts discussed here is translated into a legal - justiciable - formulation that can integrate the different sides of property and that can be projected into the debates about the desirability and dialectic of these sides.

The emphasis in this paper, therefore, is on the collective influence of the case law on the evolution of the right to property. The choice of the specific international courts has been made in order to flesh out the scope and applicability of a private right to property and to reconceptualise it as a hybrid in the highly developed legal orders of European Union (EU) law and European human rights law and in general international law. The analysis is not exhaustive. 'Test cases' of the operation of the right remain important in relation to international investment $\mathrm{law}^{9}$ and indigenous peoples, especially

7 Poul F. Kjaer, 'Introduction' in: Paulius Jurcys, Poul F. Kjaer and Ren Yatsunami (eds), Regulatory Hybridization in the Transnational Sphere (Leiden: Martinus Nijhoff/Brill 2013), 18 (3).

8 On the link between global governance, economic rights and the role of courts, ErnstUlrich Petersmann, Multilevel Constitutionalism for Multilevel Governance of Public Goods: Methodology Problems in International Law (Oxford: Hart 2017). See also, David Schneiderman, Constitutionalizing Economic Globalization: Investment Rules and Democracy's Promise (Cambridge: Cambridge University Press 2008); Benedict Kingsbury and Stephan W. Schill, 'Investor-State Arbitration as Governance: Fair and Equitable Treatment, Proportionality and the Emerging Global Administrative Law' in: Albert J. van den Berg (ed.), 50 Years of the New York Convention (Alphen aan den Rijn: Wolters Kluwer 2009), 5.

9 Enrique B. Barrera, 'Property Rights as Human Rights in International Investment Arbitration: A Critical Approach', Boston College Law Review 59 (2018), 2635-2662. 
in the human rights jurisprudence in Latin America. ${ }^{10}$ In a world where global connections thicken and continuously evolve, these contributions open the door to further research in this direction.

The paper is structured in four sections. In the first part, the theoretical framework is presented and the discussion of the right to property is placed within the dynamics of functional differentiation and hybridisation. The aim is to provide useful insights into the multiplicity of operations of property and to demonstrate the different forms it takes on, depending upon the diverse social discourses that construct it in structural coupling with law. ${ }^{11}$ In the second and third parts, the jurisprudence of the ICJ and European courts are examined in order to illustrate how the judicial interpretation of property fits within this theoretical scheme. The ICJ judgements in Barcelona Traction ${ }^{12}$ and Diallo $^{13}$ are revisited in order to evaluate how the Court dealt with the obligation of states to protect the rights of foreign companies and shareholders and to shed light on how it viewed the operation of property under international law. It is shown that the underlying formalism of the ICJ's reasoning in these cases prevented the effective protection of the rights of foreign shareholders. The Court, however, indicated that property constitutes a basic, elementary right that guarantees a degree of certainty in transnational economic relations. In this sense, it portrayed it as a transnational

10 See Section IV. for a brief discussion. S. James Anaya and Robert A. Williams, Jr., 'The Protection of Indigenous Peoples' Rights over Lands and Natural Resources Under the InterAmerican Human Rights System', Harvard Human Rights Journal 14 (2001), 33-86; Alexandra Xanthaki, Indigenous Rights and United Nations Standards: Self-determination, Culture and Land (Cambridge: Cambridge University Press 2007).

11 On polycontextual law, Gunther Teubner, 'The King's Many Bodies: The Self-Deconstruction of Law's Hierarchy', Law \& Society Review 4 (1997), 763-788 (777). 'Structural coupling' refers to instances of selective interactions between social systems. According to Luhmann, structural coupling refers to a mechanism whereby the operations of one system influence the operations of another. Property, for example, has a different meaning for the economic and the legal systems, respectively. The economic exchange of assets, which is measurable in money in the economic system, is expected to trigger a response (an irritation) in the legal system through the recognition of property rights that establish the ownership of assets. An operation or communication relating to property, therefore, is perceived differently by these systems, and structural coupling allows a system to pre-suppose 'certain features of its environment on an ongoing basis and [to rely] on them structurally'. The way that one operation is perceived and treated by another system is referred to as a process of 'irritation'. See Niklas Luhmann, Law as Social System (Oxford: Oxford University Press 2004), 382 and 379-385. For more on this, see sub-section 1. below.

12 ICJ, Case Concerning the Barcelona Traction, Light and Power Company Limited (New Application: 1962) (Belgium v. Spain) (Second Phase), judgement of 5 February 1970, ICJ Reports 1970, 3.

13 ICJ, Case Concerning Abmadou Sadio Diallo (Guinea v. DRC), preliminary objections, judgement of 24 May 2007, ICJ Reports 2007, 582; ICJ, Case Concerning Abmadou Sadio Diallo (Guinea v. DRC), merits, judgement of 30 November 2010, ICJ Reports 2010, 639. 
economic freedom and acknowledged that rules governing property rights of foreign companies and shareholders are incorporated into universal customary law and transnational investment law. It thus opened up the possibility of consolidating the rudimentary protection of property under customary international law and of taking into account the autonomies of societal activities at the translational level.

In relation to the European legal order, it is demonstrated that the jurisprudence of the CJEU and the ECtHR has advanced a conceptualisation of property which incorporates its distinct, but highly interconnected, economic and non-economic aspects. It provides a clear manifestation of the hybrid right to property as promoting the freedom to participate in economic activities and to take economic risks, as well as facilitating the protection of one's subsistence. It is argued that, by comparison to the ICJ, the two European courts have developed a degree of compatibility between the idea of property as an economic freedom and as a human right. In that way, they have contributed to the management of the normative collisions between the economic and social dimensions of property without establishing a clear hierarchical ranking. In the fourth and final section, the question is posed as to whether the hybridisation of property can provide a useful framework for interpreting the right for the benefit of indigenous communities in Latin America.

\section{Reinterpreting the Right to Property as a Hybrid}

Property has been the subject of long-standing academic debates and has been framed either separate from sovereignty or in close connection to it. In the former tradition, property and sovereignty are independent concepts: property is rooted in the private sphere and defines the freedom of individuals to manage their assets, whereas sovereignty stems from the public sphere and from the establishment of the state that is based on the social contract among its citizens. ${ }^{14}$ In principle, changes in sovereignty should not affect the protection property rights and, therefore, international law should provide guarantees to that effect. ${ }^{15}$ In the latter tradition, the establishment of political authority over a given territory entails the power to organise the domestic socioeconomic order and, by extension, to regulate the allocation of

14 For an in-depth account of the different debates, Veronika Bílková, 'Sovereignty, Property and the Russian Revolution', JHIL 19 (2017), 147-177 (150); Lorenzo Cotula, 'Land, Property and Sovereignty in International Law', Cardozo Journal of International \& Comparative Law 25 (2017), 219-286 (233).

15 Bílková (n. 14). 
property and economic resources. As Kennedy explained, the right to property has acquired an 'overwhelming strength' in international human rights instruments, but warned that its enforcement against the state 'may actively weaken the capacity of people to challenge economic arrangements' that determine how they are governed. ${ }^{16}$ Kennedy criticised the use of international human rights law as a tool 'to narrow the range of socio-economic choices available $[\ldots]$ in the name of "rights"' and to reinforce existing distributions of wealth, power, and resources in societies, especially in developing states. ${ }^{17}$ What seems to be at stake, when evaluating the international regulation of property, is that it could adversely affect local decision-making, and therefore, some 'caution' may be necessary with regard to the 'strategic choices embedded in any property regime'. ${ }^{18}$ The debate has presented useful observations on how property links to the general management of the economy in nation states and has demonstrated the interactions - often in the form of conflicts - between sovereignty and property. ${ }^{19}$

In any case, it is widely accepted that the construction of the appropriate balance between sovereignty and property is historically contingent. ${ }^{20}$ In international practice, this has been clearly reflected in the New International Economic Order (NIEO) project during the period of decolonisation. The debates at the United Nations (UN) institutional level were focused on whether economic relations should be structured on the basis of state sovereignty or a global economic order that guarantees economic freedoms through protections from unlawful expropriation. ${ }^{21}$ NIEO aimed to bring the treatment of foreign investment and property rights of foreign nationals more broadly within the remit of national law and to frame it within a broader goal of achieving global economic justice through international law. ${ }^{22}$

16 David W. Kennedy, 'The International Human Rights Movement: Part of the Problem?', Harvard Human Rights Journal 15 (2001), 101-125 (109).

17 Kennedy (n. 16), 116.

18 David W. Kennedy, 'Some Caution about Property Rights as a Recipe for Economic Development', Accounting, Economics, and Law 1 (2011), 1-62.

19 Koskenniemi (n. 1).

20 Martti Koskenniemi, 'Colonial Laws: Sources, Strategies and Lessons?', JHIL 18 (2016), 248-277.

21 Stephen M. Schwebel, 'The Story of the U. N.'s Declaration on Permanent Sovereignty over Natural Resources', American Bar Association Journal 49 (1963), 463-469; Rudolf Dolzer, 'Permanent Sovereignty over Natural Resources and Economic Decolonisation', HRLJ 7 (1986), 217-230.

22 Declaration on the Establishment of a New International Economic Order, UNGA Res S-6/3201 of 1 May 1974, A/RES/S-6/3201; Charter of Economic Rights and Duties of States, UNGA Res 3281 of 12 December 1974, A/RES/3281. See Margot E. Salomon, 'From NIEO to Now and the Unfinishable Story of Economic Justice', ICLQ 62 (2013), 31-54; Antony Anghie, 'Legal Aspects of the New International Economic Order', Humanity 6 (2015), 145-158. 
More recently, in the context of fragmentation of international law, a growing body of scholarly work has emerged that critically analyses how international investment law and international human rights law construe property. The jurisdictional and normative divergences between the two regimes have been clearly illustrated, especially when property rights of local communities come into conflict with those of transnational companies and with the transnational movement of capital. ${ }^{23} \mathrm{~A}$ possible corrective mechanism to this, as has been suggested, is to incorporate the application of public law principles in the transnational enforcement of property rights and to complement it, for instance, with the doctrines of the margin of appreciation or subsidiarity. ${ }^{24}$ Even further, the mobilisation of civil society movements, transnational peasant groups, and indigenous peoples can be a vital part of solutions to the problem of the ineffective protection of their property rights, in particular, and of their exclusion from the formal operations of the legal and economic systems, in general. ${ }^{25}$ This involves their participation in the deliberation on recognising and protecting different structures of property rights (e.g. communal property rights embedded within indigenous cultures) in order to improve their living conditions and to contribute to the sustainability of local communities. ${ }^{26}$

While the above considerations illustrate how different understandings of property play out in different contexts and at different times, it is also clear that it is not possible to formulate a legal conceptualisation of property that is adequate from the perspective of society as a whole. What needs to be examined is the 'specific societal demands' and 'developments in social structure [that] decide on how property [is] configured' and that construct its

23 Lorenzo Cotula, 'Property in a Shrinking Planet: Fault Lines in International Human Rights and Investment Law', International Journal of Law in Context 11 (2015), 113-134. For a different approach, Manuel Monteagudo, The Right to Property in Human Rights and Investment Law: a Latin American Perspective of an Unavoidable Connection, World Trade Institute, SECO Working Paper 6/2013.

24 Stephan W. Schill, 'Deference in Investment Treaty Arbitration: Re-Conceptualizing the Standard of Review', Journal of International Dispute Settlement 3 (2012), 577-607. Generally, Bruno Simma, 'Foreign Investment Arbitration: A Place for Human Rights?', ICLQ 60 (2011), 573-596; Johannes H. Fahner and Matthew Happold, 'The Human Rights Defence in International Investment Arbitration: Exploring the Limits of Systemic Integration', ICLQ 68 (2019), 741-759.

25 On this issue of exclusion, Karl-Heinz Ladeur, 'Including a Cognitive Perspective into a Vision of "Transformative Constitutionalism"' in: Achilles Skordas, Gábor Halmai and Lisa Mardikian (eds), Economic Constitutionalism in a Turbulent World (Cheltenham: Edward Elgar forthcoming 2021).

26 Olivier De Schutter and Balakrishnan Rajagopal (eds), Property Rights from Below: Commodification of Land and the Counter-Movement (London: Routledge 2019). 
meaning in diverse contexts. ${ }^{27}$ For this reason, areas such as investment law and indigenous rights are different fields where property is structured by societal communications other than those explored in this article.

The key issue analysed in the sections below is whether it is possible to advance a dynamic character of property that manifests its economic and non-economic dimensions as partially complementary. The underlying societal communications in these dimensions of property are significant in explaining how courts manage their interactions. Far from seeking to develop a unified, overarching understanding of property, the discussion examines the different layers of the right in order to make sense of the coexistence - and in the case of the European space of governance, accommodation - of prima facie diverging frames in a hybrid construct. To achieve this, the main parameters of a hybrid right to property are first explained in the next section.

\section{Hybridity and the Right to Property}

From a systems theoretical point of view, it is possible to conceive property as 'split' 28 into the diverging social rationalities of economy, politics, and law. In the economic system, property enables economic transactions under competitive market conditions; in politics, it places limits on the power of public authority and on arbitrary state interference with individual possessions; in law, it concretises permissible and non-permissible uses of property that can define the parameters both for profitable investment in the economy and for sanctioned state interference in politics. In a different context, Teubner clearly demonstrated how social fragmentation has contributed to the transformation of contract from a unitary institution of private law into an institution that appears as a simultaneous expression of a variety of rationalities. ${ }^{29} \mathrm{He}$ argued that this has led to the fragmentation of contract into several operations which take the form of an economic transaction, a productive agreement (e.g. in engineering, medicine, or finance) and a legal promise. Accordingly, this presents an innovative perspective in order to perceive the freedom of contract as the freedom of all three discourses to 'translate, to

27 Dan Wielsch, 'The Differentiation of Property: On the Development of a Foundational Legal Concept', European Property Law Journal 5 (2016), 77-104 (86).

28 Gunther Teubner, 'Contracting Worlds: Invoking Discourse Rights in Private Governance Regimes', Social and Legal Studies 9 (2000), 399-417 (404).

29 Gunther Teubner, 'In the Blind Spot: The Hybridization of Contracting', Theoretical Inquiries in Law 8 (2007), 51-71; Gunther Teubner, 'After Privatisation? The Many Autonomies of Private Law', Current Legal Probs 51 (1998) 393-424. 
transfer, to reconstruct operations of other discourses into their context, freedom of their productive misunderstanding according to their internal logic'. ${ }^{30}$

The interaction between the economy and property can be readily obvious, as economic communication is coded in terms of payment/non-payment and the acquisition and investment of property can generate profit. Nonetheless, it might seem surprising that property can find expression in the rationality of the political system which structures its operations on the communication code of having power/not having power. The link can become clear if property is viewed in politics as interwoven with the discretion of the state to take some of the fundamental decisions about the domestic economy and to exercise the right to regulate and to expropriate for a public purpose. Such decisions include the model upon which the economy is based (e. g. whether it is built on a social market or on a more deregulated AngloSaxon model) and allow the state to pursue its own variety of capitalism. ${ }^{31}$ At the same time, the function of property is directed towards setting limits to such discretion in order to prevent the exercise of arbitrary or repressive political power. In this sense, it provides safeguards from the monopolising tendency of political rationality at the expense of other social systems that would pose the risk of de-differentiation. In this case specifically, the differentiation between politics and economy would be at stake. ${ }^{32}$

Against this background, it becomes apparent that property can operate both as an economic freedom and as a human right. In its first manifestation, property represents a mechanism of structural coupling between the economy and law on the basis of which the economy achieves its self-constitutionalisation. ${ }^{33}$ As Luhmann explained, in economic terms property is

'a form of observation of objects based on a specific distinction, namely the distinction of various owners, regardless of whether this refers to ownership, or being in possession or something, or whatever. The meaning of property, therefore, lies in the disjunction of the requirements for consensus. In order to be

30 Teubner, Blind Spot (n. 29), 67.

31 Indicatively, Peter A. Hall and David Soskice (eds), Varieties of Capitalism: The Institutional Foundations of Comparative Advantage (Oxford: Oxford University Press 2001).

32 Systemic de-differentiation describes circumstances where a system's rationality expands over and 'totalises' other societal spheres of autonomy; thus, putting at risk the systemic differentiation of modern society. See Niklas Luhmann, Political Theory in the Welfare State (Berlin: deGruyter 1990). On the functional connections between law, politics and economy, Poul F. Kjaer (ed.), The Law of the Political Economy: Transformation in the Function of Law (Cambridge: Cambridge University Press 2020).

33 Gunther Teubner, 'A Constitutional Moment? The Logics of "Hitting the Bottom"' in: Poul F. Kjaer, Gunther Teubner and Alberto Febbrajo (eds), The Financial Crisis in Constitutional Perspective: The Dark Side of Functional Differentiation (Oxford: Hart 2011), 9-51. 
successful in certain communications, the owner's consent matters, and not somebody else's. The substance of property law defines the area of communication, which is specified in this way, again by reference to certain things or in other ways. ${ }^{34}$

In this context, it has the capacity to shape economic communication and constitutes a key structural element of economic relations that find expression in law. As a principle of the economic system, property is reconstructed by the legal system. Private law, therefore, translates the economic operations of exchange of property into a set of permissible actions and corresponding limitations in relation to the use of economic assets.

In systems theory, property constitutes the secondary code of economic communication. Paraphrasing Willke, the criterion for participating in economic communication becomes the ability and willingness to transact in standardised forms of property that are measured in money, which is the primary code of such communication. ${ }^{35}$ As opposed to contract, in the case of which a high degree of customisation and freedom of parties to shape their relationship is applied, property is constructed in standardised forms. ${ }^{36}$ Without a degree of standardisation, the distinction of operations of property in the economy and law would collapse, as there would be the possibility of dealing with property without the possibility of a legal disposition. In Luhmann's terms

' $[\mathrm{t}]$ ransactions require distinction of distinctions (and not just movement of objects). This distinction of distinction must be capable of being stabilised over time, although (or precisely because) it is a temporal distinction itself. To put it more simply, it must be possible to ascertain and, over the course of time, remain able to ascertain, who the owner is before and after the transaction, and who is not. ${ }^{37}$

As follows from the foregoing analysis, property retains its different positions both in the economic and legal systems causing their mutual irritation, i.e. it triggers a response in each system which perceives and 'translates'

34 Luhmann (n. 11), 392 (emphasis in the original).

35 Helmut Willke, Smart Governance: Governing the Global Knowledge Society (Frankfurt/New York: Campus 2007), 139.

36 This is reflected by the numerus clausus principle in property law. For an extended analysis from a law and economics approach, Thomas W. Merrill and Henry E. Smith, 'Optimal Standardization in the Law of Property: The Numerus Clausus Principle', Yale L. J. 110 (2000), 1-70. Clearly, this does not preclude the flexibility to acknowledge evolution in the content or scope of property rights in order to reflect the uses of tangible and intangible assets in a dynamic market economy. Notable examples here are rights over digital currencies, options and futures. The same is true for the legal recognition of communal property rights.

37 Luhmann (n. 11), 393. 
property in accordance with its own structures. Economic principles enter the legal system and are constructed as legal principles (e.g. of property or contract law) that guarantee the operation of the autonomous sphere of economic communication. The opposite movement takes place, too, on the basis of which legal obligations and restrictions in dealings with property reenter into the economic system and bind economic operations. ${ }^{38}$ The reentry ${ }^{39}$ introduces a self-observation of the economic system and brings about the system's selective responses to events in its environment. These responses, therefore, ensure the compatibility of property dealings with social obligations emerging from other fields in society. The process of reentry can be used to balance economic criteria against other non-economic criteria of performance and read the latter into the interpretation of property. ${ }^{40}$

Moving to its second manifestation, property as a human right represents the structural coupling between politics and law. It emerges as a self-limitation of the political system that delineates the parameters and modes of state power in relation to the uses of property. ${ }^{41}$ The two forms of property as an economic freedom and as a human right are not mutually exclusive. They can simultaneously coexist as two closely interrelated but distinct social phenomena. In its human right dimension, property does not lose its connection to economic assets and to the guarantee of economic action. As such, it ensures a sphere of individual freedom protected from arbitrary exercise of state power and can facilitate integration and participation in the market. Human rights law, however, does not interpret information on property from the rest

38 Gunther Teubner, Constitutional Fragments: Societal Constitutionalism and Globalization (Oxford: Oxford University Press 2012), 112. Inger-Johanne Sand, 'Hybrid Law - Law in a Global Society of Differentiation and Change', in: Gralf-Peter Calliess, Andreas FischerLescano, Dan Wielsch and Peer Zumbansen (eds), Soziologische Jurisprudenz Festschrift für Gunther Teubner zum 65. Geburtstag am 30. April 2009 (Berlin: deGruyter 2009), 871-886 (883).

39 According to Teubner, re-entry refers to the 'reappearance of a distinction [e.g. law/ economy or law/non-law] in one of the sides of the distinction itself'. In this context, it may be said that the distinction of the economic/non-economic sides of property reappears within the economic system, but not as distinction that refers to the valuable and non-valuable forms of property. The re-entry of the distinction in the economic system is bound by its reformulation in the legal system. Gunther Teubner, 'Breaking Frames: Economic Globalisation and the Emergence of lex mercatoria', European Journal of Social Theory 5 (2002), 199-217 (205).

40 Teubner, Hitting the Bottom (n. 33), 31-34 and Teubner, Blind Spot (n. 29), 68.

41 See, Niklas Luhmann, Grundrechte als Institution: Ein Beitrag zur politischen Soziologie (6th edn, Berlin: Duncker \& Humblot 2019); Gert Verschraegen, 'Human Rights and Modern Society: A Sociological Analysis from the Perspective of Systems Theory', J. L. \& Soc. 29 (2002), 258-281 (272); Lars Viellechner, 'The Transnational Dimension of Constitutional Rights: Framing and Taming "Private" Governance beyond the State', Global Constitutionalism 8 (2019), 639-661 (647-649). 
of society through an economic lens of allocative efficiency. Through the structural coupling between politics and law, a human right to property is interpreted on the basis of non-economic objectives. ${ }^{42}$ For example, social considerations can be observed when restrictions on property are permitted in the public interest or when national measures that affect property are assessed considering their impact on the level of subsistence and hardship of the right-holder. ${ }^{43}$ Property can thus enter into the realm of the welfare state and be re-constructed on the basis of its rationality.

The operation of the right to property under diverse discourses results in its 'in-betweenness' and forms the foundations of its hybrid character. Hybridity here refers to an assemblage of different rationalities, so that property is constructed within blurred boundaries. ${ }^{44}$ As Andersen explained, hybridity is a strategy for overcoming communication gaps or potential collisions between functionally delineated discourses. The social systems 'may have rich communicative environments within which they thrive and depend on internally, but the high degree of specialisation makes communicative interaction between different functions increasingly necessary and vital but also contingent and risky'. ${ }^{45}$ Hybridity, therefore, may facilitate communication and structural couplings to ensure law's reference to - and interaction with - other social discourses. In the case of property, in particular, hybridity implies its transformation from a unitary institution of private law to a polyvalent and oscillating construct in different contexts. ${ }^{46} \mathrm{It}$ searches for the management of fragmented and colliding discourses through the accommodation of economic, legal, and political logics in conceptualising property. In a democratic system of governance based on a market economy, the different operations of property can support action that is not being subsumed by a single systemic logic and can therefore, correct systemic 'blind spots'. ${ }^{47}$ An illustration of this is provided in Section III. 2. below.

42 Teubner elaborates on the simultaneous realisation of several discursive projects as 'interdiscursive translation'. Each discourse reconstructs 'the meaning of the other in its own terms and context and at the same time can make use of the meaning material of the other discourse as external provocation to create internally something new. [... Interdiscursive translation ...] misunderstands the meaning of the agreement in the other discourse and thus creates something new.' Teubner, Contracting Worlds, (n. 28), 408.

43 For more on this point, see Section III. on the CJEU and ECtHR case law.

44 See Niels Åkerstrøm Andersen and Inger-Johanne Sand (eds), Hybrid Forms of Governance: Self-suspension of Power (London: Palgrave Macmillian 2012).

45 Niels Åkerstrøm Andersen, 'Introduction' in: Åkerstrøm Andersen and Sand (n. 44), 1, 2.

46 Generally, Sand (n. 38).

47 Tony Prosser, 'Constitutions as Communication', I CON 15 (2017) 1039-1065 (1045). 
In this backdrop, the question arises as to how property manifests itself in social systems at the transnational level, and this is the topic of analysis below. The section, first, provides an outline of the transnational context in which a hybrid right to property evolves and, then, turns to its interpretation by the ICJ, the CJEU, and the ECtHR.

\section{Judicial Interpretation of the Right to Property under Transnational Conditions}

The transnational setting is characterised by functionally differentiated regimes in diverse areas, including trade, investment protection, finance, human rights, sports, and commercial transactions, which orient themselves towards specific logics of their own. They represent 'vast architectures of patterned communication' 48 in social systems that extend beyond the nation state into the global space and produce combinations of legal and non-legal processes and norms. Economy, law, and politics are such social systems that have developed different levels of autonomy in world society.

Transnationality and transnational law have been approached in the literature from diverse theoretical perspectives. ${ }^{49}$ In systems theory, transnationality is understood as social practice beyond national borders through which norms emerge in functionally delineated areas. ${ }^{50}$ If law has developed into a global system in this context, transnational law is understood here as one of its subsystems resulting from the internal differentiation of the legal system itself. ${ }^{51}$ It forms a body of rules within highly specialised areas of social activity that supports their growth and internal coherence. Transnational law rests on a heterarchical and network-like conception of legal orders as

48 Willke (n. 35), 54. Unless otherwise specified, the terms transnational functional regimes and collisions are understood here according to the interpretation in: Andreas Fischer-Lescano and Gunther Teubner, 'Regime Collisions: The Vain Search for Legal Unity in the Fragmentation of Global Law', Michigan Journal of International Law 25 (2004), 999-1046.

49 Generally, Peer Zumbansen (ed.), The Many Lives of Transnational Law (Cambridge: Cambridge University Press 2020.

50 Poul F. Kjaer, Constitutionalism in the Global Realm, (London: Routledge 2014), 69. See also, Poul F. Kjaer, 'Global Law as Inter-Contextuality and as Inter-Legality' in: Jan Klabbers and G. Palombella (eds), The Challenge of Inter-legality (Cambridge: Cambridge University Press 2019), 302-318.

51 Achilles Skordas, 'Treaty Interpretation and Global Governance: The Role of Domestic Courts' in: Hans Peter Aust and Georg Nolte (eds), The Interpretation of International Law by Domestic Courts: Uniformity, Diversity, Convergence (Oxford: Oxford University Press 2016), 290-316. On the differentiation of law, Linda Nell, Die multiple Differenzierung des Rechts. Eine pragmatistisch-gesellschaftstheoretische Perspektive auf den globalen Rechtspluralismus (Weilerswist: Velbrück 2020). 
opposed to a formalist one based on unity and hierarchy. Transnational law regulating economic activities, for example, has especially evolutionary dynamics because it can be produced through functional networks in the global economy and relatively independently from states.

At the same time however, transnational law co-exists with other legal subsystems such as public international law, which is primarily tied up to the regulation of state actions. The development of functional differentiation does not preclude the territorial fragmentation of states that for centuries has maintained the organisation of global politics and has found expression in public international law doctrines. The global political system is constituted by territorial segments representing states and is organised around the principles of state sovereignty, sovereign equality, and territorial integrity guaranteed by the UN Charter. As the institutionalised form of global politics, the $\mathrm{UN}$ is dominated by government executives. Its law derives from the authority of states and its modes of governance are hierarchically organised around the Security Council and the General Assembly. ${ }^{52}$ UN specialised agencies deal with other spheres of social life, such as education (United Nations Educational, Scientific and Cultural Organization [UNESCO]), health (World Health Organization [WHO]), and intellectual property (World Intellectual Property Organization [WIPO]), but their operations have not gained autonomy from states and have been closely entangled with the decision-making powers of their state members. As a result, they 'remain primarily political organisations which frame and handle issues upon the basis of a political perspective'. ${ }^{53}$

As transnational law develops within and in-between diverse functional spheres and states, it is faced with normative conflicts that are prevalent in global governance (e. g. economy vs environment; economy vs cultural rights; economy vs health). ${ }^{54}$ Significantly, the management of normative conflicts and the coordination between legal orders remain one of the core questions

52 Ernst-Ulrich Petersmann, 'Time for a United Nations "Global Compact” for Integrating Human Rights into the Law of Worldwide Organizations: Lessons from European Integration', EJIL 13 (2002), 621-650.

53 Poul F. Kjaer, Constitutionalism (n. 50), 85. See Stefan Oeter, 'International Law and General Systems Theory', GYIL 44 (2001), 72-95; Clemens Mattheis, Die Konstitutionalisierung des Völkerrechts aus systemtheoretischer Sichtweise (Heidelberg: Springer 2018).

54 In relation to environment: José A. Plaza-Úbeda, Miguel Pérez-Valls, Jose J. CéspedesLorente and Belén Payán-Sánchez, 'The Contribution of Systems Theory to Sustainability in Degrowth Contexts: The Role of Subsystems', Systems Research and Behavioural Science 37 (2020), 68-81. In relation to cultural rights and public health: Juan P. Bohoslavsky and Laura Clérico, Regulación del derecho de propiedad en un contexto de extrema desigualdad y Covid19. Una mirada desde el derecho constitucional argentino e interamericano de derechos humanos, MPIL Research Paper Series No. 2020-34. 
that relate to global governance and its legitimacy. The ways in which a level of compatibility and coordination can be established have been extensively explored in the legal literature, ranging from judicial networking to a cosmopolitan vision of pluralism and to the expansion of transnational constitutional rights with horizontal effects. ${ }^{55}$ In this light, it is only by placing property within this broader normative framework of conflicts in global governance and by understanding the interaction between its economic and non-economic sides that is possible to fully capture the role of property in modern society.

Against this background, the treatment of property was brought within the remit of public international law through the international minimum standard - a set of customary international rules governing the treatment of foreign nationals and their properties within the territory of a host state irrespective of its domestic laws. ${ }^{56}$ The international minimum standard provides that property belonging to foreign nationals must not be expropriated unless for a public purpose, in a non-discriminatory manner and followed by 'prompt, adequate, and effective' compensation that is equal to the full market value of the property..$^{57}$ By guaranteeing rudimentary protections for investors abroad, the standard constitutes a structural element of transnational commerce and is applicable even in cases that are not governed by investment treaties. It, thus, has the potential to shape the position of private economic actors in the global economic system and to structure their relations with the host state. In that way, it approaches property as an economic freedom.

Moreover, the protection of property as a human right has also developed under international law. Property is not recognised as a universal human right in a binding human rights treaty, ${ }^{58}$ and even relevant provisions that appear in the International Covenant on Economic Social and Cultural Rights (e. g. Article 15(1)(c)) are restricted to the scope of intellectual property. These observations, nonetheless, do not prejudice the decentralised, regional protection of property as a human right, most notably under the

55 On the three approaches, respectively: Fischer-Lescano and Teubner (n. 48); Paul S. Berman, Global Legal Pluralism: A Jurisprudence of Law Beyond Borders (Cambridge: Cambridge University Press 2012); Viellechner (n. 41).

56 Andreas H. Roth, The Minimum Standard of International Law Applied to Aliens (Leiden: A. W. Sijthoff 1950); ICJ, Factory at Chorzow (Germany v. Poland) 1926 PtC of Arbitration (ser. A) no. 7, 1925, paras 124-125.

57 Indicatively, Stephen M. Schwebel, 'Investor-State Disputes and the Development of International Law', ASIL Proc. 98 (2004), 27-30; Andreas F. Lowenfeld, 'Investment Agreements and International Law', Colum. J. Transnat'l L. 42 (2003), 123-130; José E. Alvarez, 'A BIT on Custom', N. Y. U. J. Int'l L. \& Pol. 42 (2009), 17-80.

58 It is included in Art. 17 UDHR 1948, which does not have binding force. 
European Convention on Human Rights (ECHR), the American Convention on Human Rights and the African Charter on Human and Peoples' Rights, as well as a large number of multilateral treaties. ${ }^{59}$ In this light, Alvarez persuasively argued that fragmented, yet evolving, human rights protections are grounded in international instruments that base the right to property on human dignity and expand its enjoyment under the rule of law in a non-discriminatory and non-arbitrary basis. ${ }^{60}$ Taken together, the international minimum standard and human rights law make it possible to view property as a transnationalised right which is marked by variable levels of protection and decentralised modes of law-making. Its transnational nature designates that its expansion beyond specific national orders may benefit economic processes, but may also support the livelihoods of individuals, marginalised groups, or indigenous peoples, whose material or cultural survival has been linked to the respect and promotion of their property rights. ${ }^{61}$

\section{Property in the ICJ: A Transnational Economic Freedom from a State-centred Perspective}

As one of the central institutions of the global political system, the ICJ represents the public international law order and therefore, it has had a central role in consolidating and developing international legal doctrine in a number of seminal decisions. Its jurisprudence on economic issues, however, revolves more around sovereignty than the integration of non-state economic actors in the current architecture of the international legal order. ${ }^{62}$ As will be shown in this section, the depiction of property as a transnational economic

59 These offer piecemeal protections to movable and immovable property in specific situations or categories of right-holders, e. g. Art. 5(v) ICERD 1965, Arts 15(2) and 16(1 h) CEDAW 1979, Art. 15 International Convention on the Protection of the Rights of All Migrant Workers and Members of their Families 1990; Arts 14 and 16 ILO Convention No. 169 concerning Indigenous and Tribal Peoples 1989; Arts 5(3) and 30(3) UNCRPD 2006 and Arts 13, 14, 18, 19, 29 and 30 Convention relating to the Status of Refugees 1951.

60 José E. Alvarez, ‘The Human Right of Property', U. Miami L. Rev. 72 (2018), 580-705 (677). Generally, Christophe Golay and Ioana Cismas, The Right to Property from a Human Rights Perspective, <https://papers.ssrn.com>; John G. Sprankling, 'The Global Right to Property', Colum. J. Transnat'l L. 52 (2014), 464-505.

61 Corina Heri, 'The Human Right to Land, for Peasants and for All: Tracing the Social Function of Property to 1948', HRLR 20 (2020), 433-452.

62 Generally, Achilles Skordas, 'ICJ: Guardian of Sovereignty or Catalyst for Integration?', International Legal Theory 8 (2002), 49-73; Gleider I. Hernández, 'A Reluctant Guardian: The International Court of Justice and the Concept of "International Community", BYIL 83 (2013), 13-60. 
freedom by the ICJ fell under the purview of state sovereignty; it differed, in this sense, from the construction of economic freedoms in the EU. In the latter case, the decentralised, networked governance structures and the autonomous settings of the economy and law, that have developed at the supranational level, facilitate the participation of non-state actors in transnational social activities and are not tied to sovereignty. Overall, the ICJ's case law offers a gateway to understanding the nature and function of property under public international law and to demonstrating the key elements and potential limits of its formalist reasoning.

A core issue in both Barcelona Traction and Diallo was the diplomatic protection of shareholders under customary international law and, in particular, whether the state of the shareholders' nationality was entitled to pursue a claim of diplomatic protection on their behalf. In Barcelona Traction the Court declared Belgium's claim against Spain inadmissible and confirmed that only the state of the company's nationality had the right to rely on the diplomatic protection doctrine in this case. In its Diallo decision, it considered Guinea's claim admissible and examined whether the Democratic Republic of Congo (DRC) had violated the rights of a Guinean national and sole shareholder of two companies. On the facts of the case however, it concluded that the DRC's conduct did not amount to an infringement of Diallo's right to property.

When interpreting the rights of companies and their shareholders in Barcelona Traction, the Court recognised that the violation of property rights belonging to foreign natural or legal persons may constitute an internationally wrongful act giving rise to the international responsibility of the host state. In such cases, the company or shareholders whose direct rights have been infringed have an independent right of action that can be espoused by the state of nationality. ${ }^{63}$ Significantly, the Court referred to the profound transformation of the 'economic life of nations' resulting from the growth of transnational corporations and their influence on transnational economic relations. ${ }^{64}$ This has had a sustained impact on the law of diplomatic protection, which recognises that an injury to the rights of private economic actors can give rise to state responsibility.

Even though there is no explicit examination of the nature of the right to property in the judgement, it becomes obvious that the Court views the treatment of property of aliens as an issue that directly concerns the effectiveness of transnational business activities and the commercial interests of private actors and states. In this sense, the judgement presented a conceptua-

63 ICJ, Barcelona Traction (n. 12), 37, para. 47.

64 ICJ, Barcelona Traction (n. 12), 34, para. 37. 
lisation of property as an economic freedom enabling the effective participation of private actors in the global economy and thus, as a structuring norm of transnational economic relations. In the context of its well-known formulation of obligations erga omnes and its reference to the interests of the international community 'as a whole', the Court hinted to the possibility of striking a balance between state sovereignty and the rights of non-state economic actors, rather than prioritising one over the other. ${ }^{65}$ This broad formulation left open the prospect that the Court presented an understanding of the international community that does not exclusively comprise of states. ${ }^{66}$ At its minimum, the term could be viewed as representing a legal construct which encompasses systemic communications and includes economic actors, migration flows, and civil society organisations so that it reflects the evolving architecture of the international legal order. ${ }^{67}$ This line of reasoning could have led to a thorough consideration of the interests of the international community 'as a whole' in expanding and deepening economic relations through recognising the transnational protections of property. However, the ICJ missed such an opportunity and did not further examine the content and function of property in the transnational sphere. This can be seen in two aspects of the judgement.

First, there is no evidence that property was considered a human right. Indeed, a mention to human rights was made in passing in the judgement and only referred to protections against the denial of justice under the ECHR, without considering its link to arbitrary deprivation of property. ${ }^{68}$ Second, the content of the shareholders' rights was determined by resorting to domestic law rather than international law. ${ }^{69}$ The reason for this, according to the Court, was that international law at the time of the judgement had not established its own rules on the treatment of companies and shareholders. Even though it acknowledged investment treaties and other instruments governing the treatment of foreign property, it rejected their relevance in the field of diplomatic protection because of their lex specialis

65 ICJ, Barcelona Traction (n. 12), 33, para. 33.

66 The International Law Commission (ILC) makes a distinction between interests of states and interests of international community as a whole, which includes other subjects. ILC, Draft Articles on Responsibility of States for Internationally Wrongful Acts, with Commentaries (2001), 35, para. 8; 84, para. 18; 89, para. 5 and 95, para. 4; James R. Crawford, 'Responsibility of the International Community as a Whole', Ind. J. Global Legal Stud. 8 (2001), 303-322.

67 On the concept of the international community, Bruno Simma and Andreas L. Paulus, 'The "International Community": Facing the Challenge of Globalization', EJIL 9 (1998), 266277; Dino Kritsiotis, 'Imagining the International Community', EJIL 13 (2002), 961-992.

68 ICJ, Barcelona Traction (n. 12), 48, para. 91; Separate Opinion of Judge Gros, 274, para. 12.

69 ICJ, Barcelona Traction (n. 12), 34, para. 38. 
character. ${ }^{70}$ Consequently, it held that the relevant rights of shareholders were only those that were recognised under national law. The ICJ, thus, relied on the private law doctrine of separate legal personality between a company and its shareholders which fell within the domain of the domestic jurisdiction of states. ${ }^{71}$

Through recourse to national law, the property rights of shareholders and corporate entities were dealt with as an issue concerning the relationship between private parties governed by domestic private law. On this basis, Judge Riphagen in his dissenting opinion in Barcelona Traction criticised the judgement for failing to appreciate the nature of the rules of customary international law on the treatment of aliens. According to Judge Riphagen, this body of rules draws its inspiration 'from the interest of the international community in respect for the fundamental freedoms of the human person as well as in respect for the freedom of international commerce' ${ }^{72}$ In this light, one can observe the regressive elements of the judgement: the Court did not fully engage with the transnationalisation of property and eventually submitted its protection to state sovereignty. Rather than recognising that international law had a significant role to play in the treatment of aliens as a direct transnational concern for human rights and economic freedoms, it followed a different interpretative path. It construed the protection of economic independence of states as an underlying rationale of the judgement. ${ }^{73}$ It then applied this reasoning irrespective of the fact that the dispute did not concern a conflict between capital-importing and capital-exporting states nor did it relate to the issue of state sovereignty over natural resources. ${ }^{74}$ More broadly, the Court's view represented international law 'as a specific disciplinary field devoted to the interactions between sovereign public actors, while the governance of the [... economy ....] was relegated to the domestic sphere, to be managed distinctly by each national polity'. ${ }^{75}$ The

70 ICJ, Barcelona Traction (n. 12), 41, paras. 61-62. Indicatively, Richard B. Lillich, 'Two Perspectives on the Barcelona Traction Case', AJIL 65 (1971) 522-532; Ian A. Laird, 'A Community of Destiny - The Barcelona Traction Case and the Development of Shareholder Rights to Bring Investment Claims' in: Todd Weiler (ed.), International Investment Law and Arbitration (Cameron 2005), 77-96; Frederick A. Mann, 'The Protection of Shareholders' Interests in the Light of the Barcelona Traction Case', AJIL 67 (1973), 259-274.

71 ICJ, Barcelona Traction (n. 12), para. 38.

72 Dissenting Opinion of Judge Riphagen, 342, para. 10. See also Separate Opinion of Judge Jessup, 12, para. 12 and 170-171, para. 17.

73 ICJ, Barcelona Traction (n. 12), 47-48, para. 89.

74 Separate Opinions of Judge Jessup, 165-166, para. 10 and Judge Gros, especially 274-279, paras 12-17.

75 Horatia Muir Watt, 'Private International Law Beyond the Schism', Transnational Legal Theory 2 (2011) 347-428 (358). Generally, Mark Hirschboeck, 'Conceptualizing the Relationship Between International Human Rights Law and Private International Law', Harv. Int'l L.J. 60 (2019), 181-199. 
formalist conception of the 'domestication of private law', ${ }^{76}$ including property rights of corporate entities and shareholders, formed a central factor in the Court's reasoning. ${ }^{77}$ As a result, the substantive content of the property rights of foreign shareholders regressed to the national legal sphere.

The reluctance of the ICJ to fundamentally change its reasoning and promote economic integration is also apparent in its 2010 decision in Diallo. One of the central elements of the judgement is that the Court drew a distinction between the human rights of Diallo as an individual on the one hand, and his rights as an associe of two companies, on the other. The first category concerned the right not to be arbitrarily expelled, the right to liberty and the right not to be mistreated while detained. The second category included the right to take part and vote in general meetings, to appoint and be appointed as a gérant, to oversee and monitor the management of the companies and, finally, the right to property over his parts sociales. Significantly, the separation of property rights from human rights is also supported by the International Law Commission (ILC) commentary on the Draft Article on State Responsibility. The commentary refers to internationally wrongful acts and distinguishes acts in the field of injury to aliens and their property and in relation to their human rights, ${ }^{78}$ thus making it evident that property rights are not recognised as human rights under customary international law according to the ILC. This distinction led the Court to consider the two categories of rights separately.

As far as Diallo's human rights as an individual are concerned, the Court explained that the scope of diplomatic protection had been widened to include not only alleged violations of the minimum standard of treatment of aliens but also internationally guaranteed human rights. ${ }^{79}$ To this extent, human rights treaties, such as the International Covenant on Civil and Political Rights and the African Charter, as well as Comments of the Human Rights Committee and case law from the African Commission on Human and Peoples' Rights, the ECtHR and the Inter-American Court of Human Rights (IACtHR) offered ample evidence to support the protection of the rights in question. This part of the judgement marked an expansive approach by the Court, as it brought the relationship between human rights law and diplomatic protection at the fore of the judgement, and achieved to pull the two in the same direction. ${ }^{80}$ In this sense, the Court reviewed and interpreted

76 Muir Watt (n. 75), 378.

77 See Ben Juratowitch, 'Diplomatic Protection of Shareholders', BYIL 81 (2011), 281-323.

78 ILC, Draft Articles on Responsibility of States (n. 66), 38, paras 7 and 92, para. 5.

79 ICJ, Diallo (preliminary objections) (n. 13), 21, para. 39.

80 Eirik Bjorge, 'Ahmadou Sadio Diallo', AJIL 105 (2011), 534-540. See Annemarieke Vermeer-Künzli, 'The Subject Matters: The ICJ and Human Rights, Rights of Shareholders, and the Diallo Case', LJIL 24 (2011), 607-625. 
human rights instruments and took into account the 'substantive development on international law over recent decades in respect of the rights it accords to individuals 81 in order to bring them within the realm of diplomatic protection.

In discussing the second category of Diallo's rights as an associe, from the outset the Court acknowledged that property rights of companies and shareholders have become transnationalised beyond the scope of a specific domestic legal order, as the actions and policies of states affecting the rights of economic actors have become subject to bilateral and multilateral investment treaties and the review of investment tribunals. ${ }^{82}$ Rather problematically however, and despite these developments, the Court did not properly assess the impact of this transnational legal practice and of human rights instruments on the scope of diplomatic protection. It thus reverted to domestic law as far as the substantive content of property was concerned and concluded that there had not been an infringement of Diallo's right on the facts of this case. ${ }^{83}$ Given that the doctrine of diplomatic protection had been applied to a large number of disputes of an economic nature in the past, the contribution of international investment treaties and tribunal decisions were clearly apposite in this case. The relation of property rights to the transnational operation of commercial undertakings was raised by Judges Al-Khasawneh and Yusuf in their joint dissenting opinion. In providing a convincing interpretation of the law, they explained how the rights of investors, including shareholders, have developed both under international investment and human rights law and should therefore be incorporated within customary international law. ${ }^{84}$

Despite the limits of its approach, it is possible to argue that the distinction the Court makes between the rights of Diallo as an individual and as an associé can be interpreted so as to fit within the functionally differentiated world society. In his economic role as a shareholder, the affected individual is identified as an actor of the global economic system through his ability and willingness to buy and transfer shares and to participate in the transnational sphere. In contrast to the rules of diplomatic protection and public interna-

81 ICJ, Diallo (preliminary objections) (n. 13), 21, para. 39.

82 ICJ, Diallo (preliminary objections) (n. 13), 36-37, paras 88-90.

83 ICJ, Diallo (merits) (n. 13), 55, para. 157.

84 Joint Dissenting Opinion of Judges Al-Khasawneh and Yusuf, 71-75. For a detailed examination of international legal practice, Christoph Schreuer, 'Shareholder Protection in International Investment Law' in: Pierre-Marie Dupuy, Bardo Fassbender, Malcolm N. Shaw and Karl-Peter Sommermann (eds), Common Values in International Law - Essays in Honour of Christian Tomuschat (Kehl am Rhein: N. P. Engel 2006), 601; Pia Acconci, 'Determining the Internationally Relevant Link between a State and a Corporate Investor: Recent Trends Concerning the Application of the "Genuine Link" Test', The Journal of World Investment \& Trade 5 (2004), 139-175. 
tional law that represent the global political system, the rules governing the global economy develop through transnational networks of investment tribunals, transnational contracting (lex mercatoria) and integration regimes, such as the World Trade Organization (WTO) and the EU. ${ }^{85}$ They thus promote the expansion and deepening of economic relations outside the traditional doctrines of public international law. The ICJ's 'political' assessment of diplomatic protection did not manage to incorporate such developments and to provide effective protection to the rights of foreign shareholders. As the Court admitted, the role of the doctrine in this context had 'somewhat faded'. ${ }^{86}$ Transnational law, however, develops in structural coupling with global societal processes ${ }^{87}$ and can provide more robust protections to property as a transnational economic freedom than those envisaged by the ICJ.

The overall picture that emerges from the two judgements is that the protection of economic rights of corporations and shareholders is recognised as a structural condition of international commerce and peaceful state relations. The Court did not make any normative assessment in relation to a specific economic model that would be compatible with the promotion of such rights and avoided prescribing any particular forms of politico-economic governance within states. Nonetheless, it specified the rudimentary conditions under which transnational economic activities should be shaped. Such a structural element feeds into universal customary law, in general, and develops in a more progressive and dynamic way through transnational law, in particular. The Court therefore makes a contribution to clarifying some aspects of property under international law, but that contribution remains restricted. It would be a step forward if the Court abandoned its statecentred perspective when reviewing economic rights and freedoms and considered the integration of non-state actors and interests in the international community 'as a whole' through the appropriate interpretation of property as an economic freedom and a human right governed by transnational law. Had the Court fully taken into account the global societal processes that contribute to the evolution of property and engaged with its hybrid nature, it would have been able to provide more effective protections to the rights of Diallo.

85 See Petersmann (n. 8).

86 ICJ, Diallo (preliminary objections) (n. 13), para. 88. Contrast Diallo with the decision in ICJ, Case Concerning Elettronica Sicula (USA v. Italy), judgment of 20 July 1989, ICJ Reports 1989, 15 which was based on the 1948 Treaty of Friendship, Commerce and Navigation between the US and Italy. Sean D. Murphy, 'The ELSI Case: An Investment Dispute at the International Court of Justice', Yale J. Int'l L. 16 (1991), 391-452.

87 Gunther Teubner, 'Global Bukowina: Legal Pluralism in the World Society', in: Gunther Teubner (ed.), Global Law without a State (Dartmouth: Aldershot 1997), 3. 
The sociological significance of a hybrid right to property in increasing the capacities of non-state actors to participate in the transnational sphere through a variety of activities and in different roles can become more apparent by examining the right in the European system of governance. If the interpretation of property by the ICJ is viewed as evolving within functional differentiation which reinforces the transnational protection of the right, in Europe the hybrid nature of property is clearly entrenched. The decisions of the CJEU and the ECtHR have disconnected property from state sovereignty. More importantly, they have made a major step in linking human rights with transnational economic freedoms and in highlighting the hybridity of property. The jurisprudence of the two courts is examined together in the next section as there is a degree of overlap between their approaches. The courts mutually influence one another and develop a line of case law that gives rise to a transnational hybrid right.

\section{Beyond Dichotomies: A Hybrid Right to Property in the European Space of Governance}

In Europe the right to property should be viewed within the complex system of governance that has emerged. It is characterised by a multilevel framework of asymmetric integration in functional areas, which encompasses the highly developed economic system of the EU at its core and, comparatively, a more elementary political order ${ }^{88}$ based on human rights protections under the ECHR in its outer circle. ${ }^{89}$ In that way, it consists of overlapping, mutually reinforcing, and partially colliding constitutional orders which rely

88 The rule of law deficiencies in EU Member States, such as Poland and Hungary, alongside the responses of EU institutions in monitoring and strengthening compliance with EU law and principles under Art. 2 TEU, have brought the political aspects of integration more to the fore. However, it would be premature to conclude that the political system has moved to the centre of EU governance given that it has not gained autonomy from the national political systems of the Member States and remains entangled with them. See Jiri Priban, 'The SelfReferential European Polity, its Legal Context and Systemic Differentiation: Theoretical Reflections on the Emergence of the EU's Political and Legal Autopoiesis', ELJ 15 (2009), 442461; Armin von Bogdandy and Michael Ioannidis, 'Systemic Deficiency in the Rule of Law: What It Is, What Has Been, What Can Be Done', CML Rev. 51 (2014), 59; European Commission, 2020 Rule of Law Report: The Rule of Law Situation in the European Union COM (2020) 580 final; ECJ, EC v. Poland, judgment of 24 June 2019, case no. C-619/18, ECLI:EU: C:2019:531.

89 Achilles Skordas, 'Is Europe an Aging Power with Global Vision - A Tale on Constitutionalism and Restoration', Columbia Journal of European Law 12 (2005), 241-291 (288); Poul F. Kjaer, 'The Transnational Constitution of Europe's Social Market Economies: A Question of Constitutional Imbalances?', JCMS 1 (2019), 143-158. 
upon the particular logic of the societal field in which they operate. In light of the high level of economic and, to a lesser extent, political integration in the region, as well as the judicial comity that guides the practice of the CJEU and the ECtHR, the right to property reaches beyond the boundaries of domestic legal orders and includes differentiated levels of enforcement in the EU and the ECHR that provide clear evidence of its transnational scope. In this context, the protection of property is considerably different than under international law. Its hybridity is evident in the reasoning of the two courts whose interpretation of property is oscillating between its economic and social dimensions. A hybrid right to property in this context accommodates the autonomy of economic operations. At the same time, it involves the review of national and EU measures in order to safeguard the social dimensions of property in cases where an excessive economic rationality or political logic could have adverse effects on other societal fields and on individual claimants. That way, the interpretation of the right in Europe manages to reconcile the occasional tensions that arise between the economic and noneconomic performances of property and thereby, to render them complementary.

\section{a) A Right to Property as an Aspect of the Human Rights and Economic Integration Agendas}

The ECHR regime represents the common public order of human rights in Europe and has developed a specialism in the promotion of a discourse of democracy and human rights from a political perspective. ${ }^{90}$ In relation to the right to property under Article 1 of Protocol 1 (A1-P1), this can be demonstrated, for example, by the particularly wide margin of appreciation that the Court applies with respect to its implementation. On this basis, A1-P1 is interpreted so as to permit the co-existence of a variety of economic and social models that the state parties to the Convention adopt and to acknowledge the political sensitivity of welfare policies, economic planning and structural reforms that may interfere with property. ${ }^{91}$ Despite the political orientation of the regime, the ECtHR has provided a progressive interpreta-

90 Yannis A. Stivachtis and Michael W. Habegger, 'The Council of Europe: The Institutional Limits of Contemporary European International Society?', European Integration 33 (2011), 159-177 (163).

91 Indicatively, ECtHR, Case of James and Others v. UK, judgment of 21 February 1986, application no. 8793/79; ECtHR, Case of the Former King of Greece v. Greece, judgment of 28 November 2002, application no. 25701/94. See Jan Zglinski, 'Doing Too Little or Too Much? Private Law Before the European Court of Human Rights', YBEL 37 (2018), 98-129 (110). 
tion of A1-P1 that is reinforced by a comprehensive system of human rights protections, democracy and the rule of law that spans across all sectors of society, including the economy.

Therefore, while economic freedoms associated with the right to property, such as the freedom to trade and to invest, do not fall within the direct scope of the Convention, the Court has explicitly taken into account the economic dimensions of property by applying it to individuals and corporate actors pursuing economic activities. This is apparent when the Court identifies core business operations as relevant to A1-P1. In such cases, its reasoning goes beyond the examination of the ownership or use of existing and future assets and focuses on the commercial function of these activities. ${ }^{92}$ In Van Marle, for instance, the ECtHR recognised that relations with customers and the loss of clientèle are part of 'goodwill', which affects the value of the business and thus, forms an integral part of property. ${ }^{93}$ The Court has also recognised shareholding and rights that are associated with it under the scope of A1-P1, 94 as well as proprietary rights, such as leases and statutory compensation arising from contractual and non-contractual rights. ${ }^{95}$ In this sense, the enforcement of A1-P1 is clearly interconnected with the regulation of economic activities embodied within the protection of property. As Becker points out, '[a]ny modern economy is dependent upon corporate ownership, which has in many areas replaced individual entrepreneurship. Thus, a well-established transformation of the organizational structures in the economy has to be mirrored in the structure of the

92 E.g. ECtHR, Case of Antares Transport and Transroby v. Romania, judgment of 15 December 2015, application no. 27227/08.

93 ECtHR, Case of Van Marle v. Netherlands, judgment of 26 June 1986, application nos. 8543/79 etc., paras 41-42.

94 ECtHR, Ankarcrona v. Sweden, judgment of 27 June 2000, application no. 35178/97; ECtHR, Olczak v. Poland, judgment of 7 November 2002, application no. 30417/96. Indicatively, see also cases where the ECtHR has discussed situations that justify lifting the corporate veil of limited liability companies in order to recognise the victim status of shareholders when state actions have been aimed at the property of the company: ECtHR, Case of Lekić v. Slovenia, judgment of 11 December 2018, application no. 36480/07 and ECtHR, Case of Glas Nadezhda EOOD and Anatoliy Elenkov v. Bulgaria, judgment of 11 October 2007, application no. 14134/02; ECtHR, Case of Ališic and Others v. Bosnia and Herzegovina, Croatia, Serbia, Slovenia and the former Yugoslav Republic of Macedonia, judgment of 16 July 2014, application no. 60642/08; ECtHR, Case of Albert and Others v. Hungary, judgment of 7 July 2020 application no. 5294/14.

95 Florian Becker, 'Market Regulation and the 'Right to Property' in the European Economic Constitution', YBEL 26 (2007), 255-296 (272): ECtHR, Case of Bosphorus v. Ireland, judgment of 30 June 2005, application no. 45036/98, (regarding a leasing contract); ECtHR, Case of Pressos Compania Naviera v. Belgium, judgment of 20 November 1995, application no. 17849/91, (regarding statuary compensation). 
legal right protecting property. ${ }^{96}$ The ECtHR appears to have taken such developments seriously.

If the ECHR represents a 'thin'97 version of political integration in Europe, the EU constitutes a vanguard actor with more advanced forms of functional governance and high degrees of specialisation in expanding transnational economic freedoms and the operation of the internal market. The four market freedoms are foundational elements of the EU's economic constitution and are supplemented by legal guarantees under the Charter of Fundamental Rights, as well as by other legal fields in areas such as labour law, consumer law and anti-discrimination. ${ }^{98}$ The Charter includes the right to property (Article 17), the freedom to choose an occupation and the right to engage in work (Article 15, partially reinforcing the free movement of factors of production) and the freedom to conduct business (Article 16). ${ }^{99}$ The right to property in particular is inbuilt into the EU's economic constitution, which is orientated towards deepening economic integration, and is effectively enforced by the CJEU, often in conjunction with the freedom to pursue trade, business, or an economic activity. ${ }^{100}$ Property-related disputes can be explicitly dealt with by the Court through an economic frame under the law of the internal market. For example, rights held by shareholders are adjudicated in the context of the freedom of establishment, ${ }^{101}$ and investment in real estate is protected within the scope of the free movement of capital. ${ }^{102}$ In stark contrast with the ICJ, the CJEU has managed to extend the protection of property within an advanced framework of supranational law which introduces the promotion of economic freedoms at an equal constitutional

96 Becker (n. 95), 271.

97 Stivachtis and Habegger (n. 90), 159.

98 Hans-Wolfgang Micklitz, 'Social Justice and Access Justice in Private Law', EUI Working Paper Law No. 2011/02.

99 See ECJ, Alemo-Herron v. Parkwood Leisure, judgment of 18 July 2013, case no. C-426/ 11, ECLI:EU:C:2013:521. Significantly, see CJEU, Yusuf and Al Barakaat International Foundation v. Council and Commission, judgment of 21 September 2005, case no. T-306/01, ECR II- 3533, para. 293: the CJEU acknowledged that an arbitrary deprivation of the right to property can be regarded as contrary to $j u s$ cogens.

100 ECJ, Germany v. Council, judgment of 5 October 1994, case no. C-280/93 ECR I-497, EU:C:1994:367; ECJ, Alliance for Natural Health v. Secretary of State for Health, judgment of 12 July 2005, joined cases nos C-154/04 and C-155/04 ECR I-6451, ECLI:EU:C:2005:449. See also, ECJ, Liselotte Hauer v. Land Rheinland-Pfalz, judgment of 13 December 1979, case no. 44/79 ECR 3727, ECLI:EU:C:1979:290.

101 ECJ, Commission v. Netherlands, judgment of 28 September 2006, joined cases nos C282/04 and C-283/04 ECR I-9141, ECLI:EU:C:2006:608; ECJ, Centros v. Erhvervs-og Selskabsstyrelsen, judgment of 9 March 1999, case no. C-212/97 ECR I-01459, ECLI:EU: C:1999:126.

102 ECJ, Konle v. Austria, judgment of 1 June 1999, case no. 302/97 ECR I-3122, ECLI:EU: C:1999:271. 
value and rank with fundamental rights. ${ }^{103}$ In this sense, it has drawn inspiration from the ECHR and approaches property as a human right and at the same time as an economic freedom that is closely intertwined with the Union's economic constitution.

One potential obstacle to the expansive protection of property in the EU could be considered Article 345 Treaty on the Functioning of the European Union (TFEU), which provides that EU law should not be prejudicial to the national systems of property ownership. In light of this, the argument has been put forward that Article 345 permits the imposition of restrictions on economic freedoms by submitting them to state sovereignty. Advocate-General Ruiz-Jarabo Colomer has claimed that the system of property ownership should be understood in an economic sense: it provides a means for national authorities to retain public control over private corporate undertakings of strategic interest for the domestic economy in order to impose economic policy objectives and to influence economic life. ${ }^{104}$ According to the Advocate-General, this is precisely 'the matter reserved to the sovereignty of the Member States'105 on the basis of Article 345.

This argument has been firmly rejected by the CJEU, which has clarified that Member States could not 'plead their own systems of property ownership, referred to in Article [345], by way of justification for obstacles [...] to the exercise of the freedoms provided for by the Treaty'. ${ }^{106}$ The Court departs from the Advocate-General's conclusion on the basis of a different understanding of the relationship between national systems of property and economic freedoms in the context of the Union's economic constitution. In this sense, domestic legal frameworks of property remain subject to review under EU law on economic freedoms and must be interpreted in a manner consistent with the functioning of the internal market. ${ }^{107}$ While the aim of

103 Charles F. Sabel and Oliver Gerstenberg, 'Constitutionalising an Overlapping Consensus: The ECJ and the Emergence of a Coordinate Constitutional Order', ELJ 16 (2010), 511550.

104 Opinion of Advocate-General Ruiz-Jarabo Colomer in ECJ, Commission v. Portugal, judgment of 4 June 2002, case no. C-367/98 ECR I-04731, ECLI:EU:C:2002:326, paras 53-62. For a contrary view, Opinion of Advocate-General Roemer in ECJ, Consten and Grundig v. Commission, judgment of 13 July 1966, joined Cases 56 and 58-64, ECR 00429, 1 ECLI:EU: C:1966:41, 366.

105 Advocate-General Ruiz-Jarabo Colomer (n. 104), para. 62.

106 ECJ, Commission v. Spain, judgment of 13 May 2003, case no. C-463/00 ECR I-4606, ECLI:EU:C:2003:272, para. 67.

107 ECJ, Fearon v. Irish Land Commission, judgment of 6 November 1984, case no. 182/83 ECR 03677, ECLI:EU:C:1984:335, paras 5-7. See Steffen Hindelang, The Free Movement of Capital and Foreign Direct Investment: The Scope of Protection in EU Law (Oxford: Oxford University Press 2009), 248-252; Peter Sparkes, European Land Law (Oxford: Hart 2007), 109118. 
EU law is not to harmonise property systems, their entanglement with economic activity brings them within the ambit of supranational law that transcends the legal orders of specific Member States.

The framing of the protection of a hybrid right to property in both the economic and political areas of governance in Europe achieves to further the self-organisation capacities of economic actors in the transnational sphere but also to render their activities compatible with non-economic objectives. This latter aspect is discussed below by focusing on how the CJEU and the ECtHR have managed to reconcile the normative collisions between the economic and social dimensions of property.

\section{b) The Economic and Social Dimensions of Property}

The expansive interpretation of elements of property of a distinctively economic nature by the CJEU and the ECtHR has attracted the criticism that the courts abstract property from its social context and interpret it on the basis of an economic model which focuses on the generation of profit and the objective market value of assets. ${ }^{108}$ With respect to the ECtHR case law, Allen has pointed out that ' $[\mathrm{i}]$ ncreasingly, the free market represents the norm for judging all State action affecting property, and the Court cannot even conceptualize an alternative perspective on [A1-P1]'. ${ }^{109}$ More recently, this criticism has been extended to the approach of both courts towards the interpretation of property in the context of the economic and sovereign debt crisis in Europe. ${ }^{110}$

It is argued here that the relevant jurisprudence does not demonstrate that the courts have been oblivious to the social function of property nor that they have failed to take into account the non-economic considerations implicated in specific cases. The line of case law is more complex and nuanced in two ways. First, both courts have recognised that the economic nature of some forms of property entails significant financial risk which, by itself, may lead to partial or even total loss of the value of property. In this context, the courts have assumed that such intrinsic risks and hazards are

108 For a critique on the impact of economic crisis on the protection of social rights, David Bilchitz, 'Socio-economic Rights, Economic Crisis, and Legal Doctrine', I CON 12 (2014), 710-739; Margot E. Salomon, 'Of Austerity, Human Rights and International Institutions', ELJ 21 (2015), 521-545.

109 Tom Allen, 'Liberalism, Social Democracy and the Value of Property under the European Convention on Human Rights', ICLQ 59 (2010), 1055-1078 (1056).

110 Generally, Claire Kilpatrick and Bruno De Witte, 'A Comparative Framing of Fundamental Rights Challenges to Social Crisis Measures in the Eurozone', SIEPS European Policy Analysis (2014), 1-9. 
knowingly undertaken by property holders, i. e. when dealing with certain economic assets, and have elevated them to relevant factors in the evaluation of the proportionality of restrictions on the right to property. Second, the CJEU and the ECtHR have managed to link the economic and social dimensions in their interpretation of the right and to switch between the two. The more risky and speculative the nature of the property in question is, the more the centre of gravity lies on its economic characteristics and therefore, the review of national measures potentially limiting the right is more lenient. On the contrary, measures that have a substantial impact on the social dimensions of property because of their impact on the subsistence, wellbeing or family home of the affected party, the more the courts turn to the non-economic logic of property as a way of reading social obligations into the sphere of the economy. The two points are illustrated below with reference to some of the most seminal cases that have been selected for the purposes of this discussion.

In Grainger 111 the ECtHR was asked to consider whether the decision of the United Kingdom government not to provide compensation to former shareholders of Northern Rock following the nationalisation of the bank constituted a violation of A1-P1. The Court took into account the wider context of the macro-economic policy of the domestic authorities and determined that the exceptional nature of the global financial crisis provided a legitimate objective in the public interest for restricting the right to property. ${ }^{112}$ More importantly, the Court assessed the proportionality of the national measures with reference to the economic characteristics of shareholding and emphasised that loss of the value of shares was an economic risk inherent in shareholding. Given that the company's assets did not offset its losses, the shareholders should not benefit from the value that would have been generated only through the provision of state support. Therefore, the fact that the applicants lost their shares and received no compensation was determined not to constitute an infringement of A1-P1. The policy of moral hazard and the economic aspects of shareholding played a significant role in the Court's reasoning: had the shareholders been allowed to benefit by receiving compensation, this would have encouraged bad business decisions by managers and shareholders in other banks on the assumption that

111 ECtHR, Case of Grainger v. UK, judgment of 10 July 2012, application no. 34940/10.

112 ECtHR, Grainger (n. 111), para. 39. See also ECtHR, Albert (n. 94), para. 167, confirming this point: 'The Court's findings above do not appear to be at variance with the standard that has emerged in the regulatory context of many of the Council of Europe member States, that of accepting fairly severe intrusive measures in respect of banks and assimilated institutions, as insufficient regulation of this sector was seen as capable of resulting in serious systemic risks for the respective economies [...].' 
the government would provide a safety net with the availability of similar support. ${ }^{113}$

This stance was repeated in Mammatas ${ }^{114}$ relating to the haircut of Greek bonds and, more recently, in Albert, ${ }^{115}$ which concerned legislation putting banks under the supervision of state authorities following the financial crisis. It was also evident in the CJEU's reasoning in Accorinti, ${ }^{116}$ Ledra $^{117}$ and Chrysostomides. ${ }^{118}$ In the relevant parts of the decision in Accorinti, the Court first established that the purchase of state bonds by an investor is by definition a transaction that entails financial risk because it is subject to the hazards of movements in the capital markets. ${ }^{119}$ Second, some of the concerned investors acquired Greek bonds, even at the peak of the financial crisis in Greece, and therefore, could not claim to have acted as prudent and circumspect economic operators able to rely on the existence of legitimate expectations. On the contrary, they should have been aware of the highly unstable economic situation affecting the fluctuation of the value of the bonds and should have appreciated the risk of at least a selective default by Greece. ${ }^{120}$ The Court then concluded that:

'such operations are carried out on particularly volatile markets, often subject to hazards and uncontrollable risks [...] which may invite speculation in order to obtain high returns in the very short term. Therefore, even on the assumption that all the applicants were not involved in speculative operations, they had to be aware of those hazards and risks of a considerable loss in the value of the bonds $[\ldots]^{121}$

Neither the CJEU in Accorinti nor the ECtHR in Grainger evaluated whether all affected property holders had, in fact, acted in a risky or speculative manner. They rather relied on the nature of the property itself, which was relatively tied to market conditions. While the protection of property is indispensable in safeguarding the spontaneity, innovation and growth-generating capacities of non-state actors, it also ensures that economic activities do

113 ECtHR, Grainger (n. 111), para. 42.

114 ECtHR, Case of Mammatas v. Greece, judgment of 21 July 2016, application nos 63066/14, 64297/14 and 66106/14, paras 54 and 118 where the ECtHR extensively relied on the CJEU's findings and reasoning in Accorinti, infra.

115 ECtHR, Albert (n. 94).

116 ECJ, Accorinti and Others v. ECB, judgment of 7 October 2015, case no. T-79/13, ECLI:EU:T:2015:756.

117 ECJ, Ledra Advertising et al v. EC and ECB, judgment of 20 September 2016, joined ECJ cases nos C-8/15 P to C-10/15 P, ECLI:EU:C:2016:701.

118 Chrysostomides v. Council and Others, judgment of 13 Jul 2018, case no. T-680/13 [2018], ECLI:EU:T:2018:486.

119 ECJ, Accorinti (n. 116), para. 82.

120 ECJ, Accorinti (n. 116), para. 82.

121 ECJ, Accorinti (n. 116), para. 121. 
not over-expand or damage the prospects of financial and economic recovery for the benefit of society as a whole. The application of the legal norms on property in this way overcomes the pure incrementalism of an exclusively economic dimension of property. Thus, it can act as a corrective mechanism that combines the strength of internal self-organisation of the economic system with external strategic guidance that develops the system's responsiveness to its environment. ${ }^{122}$

In addition to the above examples, the potential of a hybrid right to property to correct the destructive asymmetries in the growth of its economic scope over other dimensions can be illustrated by the landmark decisions in N.K.M, ${ }^{123}$ Koufaki, ${ }^{124}$ and Aziz. ${ }^{125}$ The contribution of these judgements in developing a multi-faceted conception of property is that both the CJEU and the ECtHR have read non-economic criteria into the interpretation and application of the right in order to address circumstances of social hardship when the subsistence of claimants is at risk.

In N.K.M. the ECtHR decided that the imposition of a $98 \%$ tax on severance pay of a civil servant that was entered into force weeks before her dismissal constituted a violation of A1-P1. In the crucial part of the judgement, the ECtHR emphasised that 'severance cannot be simply regarded as a pecuniary asset'. ${ }^{126}$ Considering its social function, 'the entitlement to severance allowance must be rather seen as a socially important measure intended for workers who have been made redundant and who wish to remain in the labour market'. ${ }^{127}$ In contrast to the abovementioned cases where the economic nature of an asset was a key factor in the Court's decision, here the ECtHR rejected the argument that excessive risk-taking was relevant for civil servants given that they already operated in a regulated environment of

122 See Willke (n. 35), 168 referring to this as 'contextual guidance'.

123 ECtHR, Case of N.K.M.v. Hungary, judgment of 14 May 2013, application no. 6652911. Also, ECtHR, Case of R.Sz v. Hungary, judgment of 2 July 2013, application no. 41838/11; ECtHR, Case of J.D. and A v. UK, judgment of 24 October 2019, applications nos 32949/17 and 34614/17; ECtHR, Case of Stec and others v. UK, judgment of 12 April 2006, applications nos 65731/01 and 65900/01; ECtHR, Case of Béláné Nagy v. Hungary, judgment of 13 December 2016, application no. 53080/13; ECtHR, Case of Kjartan Asmundsson v. Iceland, judgment of 12 October 2004, application no. 60669/00. See Xenophon Contiades and Alkmene Fotiadou, 'Socio-economic Rights, Economic Crisis, and Legal Doctrine: A Reply to David Bilchitz', I CON 12 (2014), 740-746.

124 ECtHR, Case of Koufaki and ADEDY v. Greece, judgment of 7 May 2013, application nos 57665/12 and 57657/12. Also, ECtHR, Case of Da Conceiçào Mateus v. Portugal, judgment of 8 October 2013, application nos 62235/12 and 57725/12.

125 ECJ, Aziz v. Caixa d'Estalvis de Catalunya, Tarragona $i$ Manresa, judgment of 14 March 2013, case no. C-415/11 ECLI:EU:C:2013:164.

126 ECtHR, N.K. M. (n. 123), para. 39.

127 ECtHR, N.K. M. (n. 123) para. 39. 
subordination. ${ }^{128}$ Instead, the Court drew a link between the applicant's right to property and Article 34 of the EU Charter (social security and social assistance), which includes benefits that provide protection in case of loss of employment. ${ }^{129}$

In this light, severance supports dismissed employees in their search for new employment and in re-entering the job market. As a result of the new tax measure however, the applicant suffered substantial deprivation of income in a period of significant pressure during unemployment. The swift change in the legal framework made any preparation 'virtually impossible' for those concerned and exposed the applicant to 'substantial personal hardships' which led to a violation of A1-P1. ${ }^{130}$ The Court thus brought the social costs that would be suffered by the applicant within the remit of the question on the infringement of the right to property. Viewed from this perspective, it is possible to argue that also the decision in Koufaki can be explained with reference to the social elements of property. Here, the ECtHR had to consider whether a reduction in salary and pension payments constituted a violation of A1-P1. On the facts of the case, salary payments were reduced from around 2,400 to 1,800 EUR, whereas the 13th and 14th months' pensions were eliminated and followed by the establishment of an annual payment ranging from 800 to 1,000 EUR. The ECtHR declared the applications inadmissible. It acknowledged, however, that if the specific national measures had adversely affected the situation of the applicants so that their subsistence was threatened, this would have been an indication of a potential breach. ${ }^{131}$ For the purposes of this discussion, the significance of the case lies in the fact that the Court recognised the relevance of well-being as a key factor that needed to be assessed in the context of A1-P1. As Kagiaros has demonstrated, the 'subsistence threshold' used in cases relating to A1-P1 has allowed the Court to consider whether individual applicants have been disproportionately affected in comparison to other parts of the population. Without establishing a minimum welfare standard, the ECtHR has been able to benefit and to 'lighten the burden' of those most severely affected by national measures. ${ }^{132}$

128 ECtHR, N.K. M. (n. 123), para. 58.

129 ECtHR, N.K. M. (n. 123), para. 70.

130 ECtHR, N.K. M. (n. 123), para. 70.

131 ECtHR, Koufaki and ADEDY (n. 124), paras 44-48. For a critical approach, Başak Çali, The European Court of Human Rights and Accountability for Neoliberal State Conduct: Never the Twain Shall Meet?, EUI Working Papers 2019/43.

132 Dimitrios Kagiaros, 'Austerity Measures at the European Court of Human Rights: Can the Court Establish a Minimum of Welfare Provisions?', European Public Law 25 (2019) 535558 (557). 
This line of reasoning is also evident in Aziz. In this case, the CJEU recognised that consumers should have a right to be granted interim relief in order to stay or terminate mortgage enforcement proceedings that could result in the eviction of a mortgagor/consumer from their home. The availability of effective protection from unfair contractual terms and the provision of remedies were closely related to the Court's concerns about the social implications of eviction from one's property. The CJEU emphasised that the principles of consumer protection apply 'all the more strongly where, as in the main proceedings, the mortgaged property is the family home of the consumer whose rights have been infringed'. ${ }^{133}$ By reviewing unfair terms in mortgage contracts, the Court framed the dispute with reference to the protection of housing and the family home and brought social considerations related to property within the scope of consumer law, a key area of the EU's internal market.

A final point that should be mentioned is that the cases discussed here mainly concern negative obligations relating to interferences with the right to property. Positive obligations are mostly manifested in procedural aspects of the right in the ECtHR case law; for example, in the form of an obligation of public authorities to act in a predictable and consistent manner, to implement measures with reasonable clarity, to act in good faith, and to adopt appropriate legal mechanisms allowing parties to effectively assert their rights against public or private parties. ${ }^{134}$ Very often these procedural aspects are closely linked to standards of good governance and have been acknowledged as such by the ECtHR. ${ }^{135}$

Proceduralisation differs from other positive obligations that require the state to fulfil the right to property, for instance, through structural or land reforms. The focus of the ECtHR on proceduralisation, however, does not detract from the hybrid character of property. The administrative, legislative, and judicial measures that create an enabling environment within Member States also help manage the complex economic and social decisions that pertain to the implementation of property rights within a domestic order. Proceduralisation may partly be an indication of two conditions. The first one is exogenous: the Court does not operate within a 'transformative' constitutional framework against a backdrop of mass poverty which is relevant to other courts (especially national constitutional ones) in other re-

133 ECtHR, Koufaki and ADEDY (n. 124), para. 61.

134 For the case law on positive obligations, Council of Europe, 'Guide on Article 1 of Protocol No. 1 to the European Convention on Human Rights', (2020), 33-38.

135 See, for example, ECtHR, Case of Păduraru v. Romania, judgment of 1 December 2005, application no. 63252/00. For relevant case law, Lisa Mardikian, 'The Right to Property as Regional Custom in Europe’, Transnational Legal Theory 9 (2018), 56-84 (66-69). 
gions. ${ }^{136}$ The second one relates to the application of the margin of appreciation doctrine and the subsidiarity principle which, inevitably, lead the Court to defer to the distributive and budgetary decisions of governments.

Having said that, the ECtHR recently drew a link between the right to property and the legal commitments of states to combat climate change in the case of Duarte Agostinho v. Portugal. ${ }^{137}$ Even though it had previously recognised that environmental protection constitutes a legitimate public interest that could justify interference with A1-P1, ${ }^{138}$ Agostinho is noteworthy for a different reason. When the Court communicated the case, it asked the applicants to comment on whether the alleged failure by 33 states to comply with their undertakings under the 2015 Paris Agreement to limit climate change and reduce greenhouse emissions has violated the applicants' right to property.

Until the Court decides on the merits, the issues in this case, admittedly, are far from settled. The ECtHR however has, at least in general terms, alluded to an interpretation of the right to property that entails positive obligations to protect the environment and hence, the living conditions and health of the applicants. The right would demand, in this context, the mitigation of destructive environmental effects which have an adverse and disproportionate impact on housing and land, as well as on the income and livelihoods/subsistence of applicants. Such a possibility to rely on A1-P1 should not be easily dismissed, as it would enable individuals, civil society actors, and local communities to press for more judicial and policy engagement with the problems of environmental degradation and climate change through the corresponding obligations within the scope of the right to property.

Concluding this section, it becomes apparent from the above analysis that both the ECtHR and the CJEU are confronted with interrelated, but often colliding, dimensions of property that underline the variety of its operations in modern society. ${ }^{139}$ They are called to interpret the right in different fields of social life and in diverse legal areas, ranging from the freedom of establishment, consumer law and employment law to monetary policy and structural economic reforms. What is remarkable in their approaches is that both courts manage to identify the 'interplay of different worlds of meaning'140 of prop-

136 The South African Constitutional Court is a notable example. Sandra Liebenberg, Socioeconomic Rights: Adjudication Under a Transformative Constitution (Claremont: Juta 2010); Ladeur (n. 25).

137 Duarte Agostinho and Others v. Portugal and 32 Other States, Communication of 13 November 2020.

138 ECtHR, Case of G. I. E. M. S.r.l. and Others v. Italy, judgment of 28 June 2018, application nos. 1828/06 et al.

139 See Fischer-Lescano and Teubner (n. 48).

140 Teubner, Blind Spot (n. 29), 67. 
erty in the economy and the welfare state and to achieve a level of compatibility between them. They thus foster an iterative process of dialogue across difference without the establishment of hierarchies. ${ }^{141}$ As Micklitz argued in light of social fragmentation:

'[d]ecision-making through adjudication is no more than a means to manage differences: differences in the respective policy field itself in weighing consumer rights and the rights of the supplier or service provider, differences between policy fields (e. g. weighing environmental protection rights against consumer protection rights), but also managing differences between identity-based rights where the holder of the rights has merged with the policy field into an indivisible conglomerate (the collective and the societal dimension) [...].' ${ }^{142}$

In that way, a hybrid right to property takes root in a variety of fields of society and this is evident in the aforementioned case law.

Hybridity challenges the assumption that only a homogenous body of social norms ${ }^{\prime 143}$ can construct the meaning of the right to property. It ensures that it is translated into multiple discourses that extend the protection of property against the monopolising tendency of one social system. This links back to the 'freedom of translation' referred to in Section II. 1., which sets in motion a potentially productive interrelation between different social languages. ${ }^{144}$ It opens up the perspective of conceptualising the protection of property as a measure for reviewing arbitrary political practices, as in N.K.M., but also the compulsion of growth of other social systems that is manifested, for example, in economic activities that may lead to socially harmful results, as in Aziz.

\section{Hybridity Beyond Private Property: Indigenous Rights and the IACtHR}

Having analysed the hybridisation of the right to property and its manifestation in Europe, the above observations may be used to interpret property

141 Paul S. Berman, 'Can Global Legal Pluralism Be Both “Global” and "Pluralist”?', Duke J. Comp. \& Int'l L. 29 (2019), 381-403.

142 Hans-Wolfgang Micklitz, 'The Constitutional Transformation of Private Law Pillars Through the CJEU' in: Hugh Collins (ed.), European Contract Law and the Charter of Fundamental Rights (Mortsel: Intersentia Uitgevers NC 2017), 49-91 (69).

143 Karl-Heinz Ladeur, 'A Critique of Balancing and the Principle of Proportionality in Constitutional Law - a Case for “Impersonal Rights”?', Transnational Legal Theory 7 (2016), 228-256 (235).

144 Teubner, Contracting Worlds (n. 28), 409. 
in other regions of the world, such as Latin America, where the case law of the IACtHR has contributed to developing comprehensive protections for communal property of indigenous peoples. Various questions therefore arise which carry both theoretical and practical significance. Can the process of hybridisation of the right to property provide a useful framework for conceptualising property in different regions? This is especially relevant in specific contexts where extreme poverty, inequality, and marginalisation of large parts of the population constitute structural reasons for their exclusion from the formal operation of different function systems, including the economy, politics, law, health, and education. How are other types of property, such as communal land rights, embedded into the cultural heritage of indigenous peoples and how does this impact on our understanding of the function of property? How are such land rights, which are closely linked with the livelihood and culture of indigenous groups, affected by the global competition for access to and control over scarce resources? Big investment projects, for instance, may collide with the property rights of local communities whose material survival and way of life depend on the use of communal or ancestral lands. As international law plays an increasingly important role in the protection of property rights in their various configurations, it brings to the fore these key normative issues about the nature of property. Some tentative comments are provided below with a view to demonstrating the potential of the argument presented in this article to be developed in such contexts.

To address the above, it would be necessary to place the examination of property within a normative framework about wider conflicts that are at the heart of global governance and transnational law, i. e. global economy vs local communities or global norms on property rights vs regional cultures in world society. ${ }^{145}$ Indeed, a transnationalised right to property is encountered by alternative forms of property that emerge as a result of diverse regional cultures, as is most evident in Latin America. While international and regional legal principles have developed that aim to protect indigenous communities, the collisions between private and communal property rights remain highly visible and accentuated.

On a broader level, a hybrid right to property is oriented toward facilitating access of the entire population into social systems in order to counter

145 On regional cultures in world society, Rudolf Stichweh, 'The Eigenstructures in World Society and the Regional Cultures of the World' in: Ino Rossi (ed.), Frontiers of Globalization Research (Boston, MA: Springer 2007), 133-149; Aldo Mascareño, 'La cultura chilena como ficción real' in: Maximiliano Figueroa and Manuel Vicuña (eds), El Chile del Bicentenario. Aportes para el debate (Santiago: Ediciones Universidad Diego Portales 2008) 181-239. Bohoslavsky and Clérico (n. 54). 
modalities of inequality in situations of mass poverty. It includes negative as well as positive obligations to strengthen institutions of governance and may have a 'transformative' impact on the living conditions of marginalised parts of the population. ${ }^{146}$ Alongside property, guarantees for the right to food, water, education, and health create an enabling environment for access to the legal system and demand the responsiveness of institutions to facilitate their fulfilment. ${ }^{147}$

On a more specific level concerning indigenous groups, the protection of ancestral land and natural resources is closely interwoven with their cultural heritage, customs and healthy living conditions, rather than their distinct economic development. In this sense, the differentiation between forms of systemic communication may be blurred or even non-existent within indigenous social structures. This suggests, therefore, that the operation of property in such circumstances is not shaped by structural couplings between the same functionally differentiated communications of the economic, political, and legal systems, as in the case of private property. Here, the IACtHR has played an instrumental role in construing an alternative, justiciable form of property. In its jurisprudence, the Court has recognised the right to property as a basis for protecting the cultural identity (as well as right to a healthy environment) of communities which had previously been excluded from formal property systems. ${ }^{148}$ It has expanded it, in other words, to a right for the defense of indigenous culture per se and its coordination with other societal processes.

Overall therefore, the framework of a hybrid right to property allows us to deal not only with its subjective addressees (a legal or natural entity or a

146 Armin von Bogdandy, Pedro Ugarte Salazar, Mariela Morales Antoniazzi and Franz C. Ebert (eds), El constitucionalismo transformador en América Latina y el derecho económico internacional. De la tensión al diálogo, (Mexico: UNAM 2018).

147 See Ladeur (n. 25). Generally, Aldo Mascareño and Fabiola Carvajal, 'The Different Faces of Inclusion and Exclusion', CEPAL Review 116 (2016), 127-141 (128); Aldo Mascareño, Diferenciación y contingencia en América Latina (Santiago, Chile: Ediciones Universidad Alberto Hurtado 2013) 2010; Jochen Kleinschmidt and Pablo Gallego Pérez, 'Differentiation Theory and the Ontologies of Regionalism in Latin America', Revista Brasileira de Política Internacional 60 (2017), 1-21.

148 Indicatively, CorteIDH, Caso Comunidades Indígenas Miembros de la Asociacion Lhaka Honhat v. Argentina, judgment 6 February 2020, paras 243-254 (where property was linked to the right to a healthy environment, water, food and cultural identity). See also, CorteIDH, Caso Comunidad Indígena Xákmok Kásek v. Paraguay, judgment of 24 August 2010, para. 282. On the link between property, indigenous culture and the right to a healthy environment, CorteIDH, Opinión Consultiva OC-23/17, Medio Ambiente y Derechos Humanos, 15 November 2017, para. 48. See Inter-American Commission on Human Rights, Indigenous and Tribal Peoples' Rights over their Ancestral Lands and Natural Resources, 30.12.2009, OEA/Ser.L/V/II, Doc. 56/ 09. 
group) but with the trans-subjective communication processes that are involved in exercising the right. In this case, the core issue is not only the legal definition of property as such, but its embeddedness into the cultural heritage of indigenous groups. ${ }^{149} \mathrm{~A}$ hybrid right would thus be attributed to the cultural processes that produce alternative forms of property. This means recognising 'indigenous communication processes themselves as the holders of fundamental rights, with appropriate legal protection measures designed to meet their needs', ${ }^{150}$ by including, but not being limited to, communal property rights and rights to participation and consultation.

\section{Conclusion}

The article has attempted to show that a transnational, hybrid right to property emerges at the levels of universal customary law, EU law, and European human rights law in the territory of the Council of Europe. It reconciles its operation in the economy, politics, and law, thereby constantly reproducing a multi-faceted view of property within separate fields of a functionally differentiated and complex society. The ICJ's case law is characterised by an acknowledgement of the transnational scope of the right and its impact on economic relations but ultimately falls short of shifting from a state-centred to an integrationist perspective. The CJEU and the ECtHR have played a crucial role in demonstrating how the interpretation of a legal right to property can receive information from the economy and politics and to mediate between its manifestation as an economic freedom and a human right. This has brought the two courts at the forefront of engaging with a hybrid right, but it is possible to observe processes of hybridisation with regional characteristics also in Latin America and the case law of the IACtHR.

Inevitably, hybridity entails a high degree of ambiguity and uncertainty. What the example of property illustrates however is that its inbuilt flexibility and capacity to support an inter-systemic level of discourse render it a viable framework for conceptualising the coordination of its different functions. It is constantly oscillating between an economic freedom and a human right without fully mutating into one or the other in rapidly changing societal practices at the transnational level.

149 For an extensive analysis, Teubner (n. 38), 162-171.

150 Teubner (n. 38), 170. Generally, Siegfried Wiessner, 'The Cultural Rights of Indigenous Peoples: Achievements and Continuing Challenges', EJIL 22 (2011), 121-140. 
